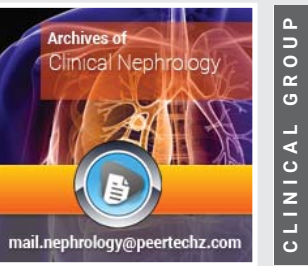

\title{
Current approach to contrast nephropathy
}

\section{Hüsnü Değirmenci*, Eftal Murat Bakırcı and Hikmet Hamur}

Associate Professor, Department of Cardiology, Faculty of Medicine, Erzincan Binali Yıldırım University, Turkey
Received: 27 October, 2020

Accepted: 27 November, 2020

Published: 28 November, 2020

*Corresponding author: Hüsnü Değirmenci, Associate Professor, Department of Cardiology, Faculty of Medicine, Erzincan Binali Yıldırım University, Turkey, Tel: 05304645530; E-mail: husnudr1982@gmail.com

Keywords: Contrast nephropathy; Radiological procedures; Renal failure; Hospitalisation

https://www.peertechz.com

\section{Abstract}

Contrast nephropathy is the third most common cause of hospital acquired acute renal failure. With the increasing use of contrast media in radiological procedures it has become one of the major challenges encountered during routine cardiology practice. Contrast nephropathy leads to undesirable clinical circumstances which may result in dead as well as increasing length of hospitalisation and high costs. For these reasons, we present contrast nephropathy in this mini review.

\section{Introduction}

Sudden deterioration in renal functions following the administration of ionized contrast material is called Contrast Nephropathy (CN). CN can lead to complications ranging from acute tubular damage to severe renal failure. While it is observed in $1-2 \%$ in the normal population, the incidence of risk factors such as diabetic nephropathy increases to $50 \%[1,2]$. CN is the third leading cause of hospital acquired renal failure [3]. However, this deficiency is often reversible. When evaluated from the cardiologist's point of view, the most common cause of $\mathrm{CN}$ is contrast agents used for imaging methods such as coronary angiography and multislice computed tomography. $\mathrm{CN}$ is a condition that increases hospitalization time, morbidity and mortality [4]. Because of its importance, we present contrast nephropathy in this review.

\section{Pathogenesis}

Mechanisms such as free oxygen radical damage, diuresis caused by contrast, increased urinary viscosity, inflammation, direct toxicity, tubular toxicity, increased oxygen consumption and renal vasoconstriction are involved in the pathogenesis $[5,6]$.

\section{Risk factors}

Renal disease history, diabetes and advanced age are the most common risk factors. However, chronic heart failure, hypertension, dehydration, nephrotoxins (aminoglycoside, nonsteroidal anti-inflammatory, cyclosporine), anemia, periprocedural bleeding and female gender are other risk factors [5].

\section{Definition}

There are several definitions for nephropathy. If the serum creatinine value rises 1.5 times the basal value within 1 week or the urine output is below $0.5 \mathrm{ml} / \mathrm{kg}$ / hour within 6 hours after the procedure, it suggests nephropathy [7]. Looking at another definition, an increase of $0.5 \mathrm{mg} / \mathrm{dl}<$ or an increase of $25 \%$ $<$ in serum basal creatine level 48-72 hours after exposure to contrast media is called CN [1]. If the creatinine value in the last 3 months is unknown, the creatinine value within 24 hours after contrast medium administration should be checked. This value is considered as reference value.

\section{Prevention}

Risk factors of $\mathrm{CN}$ are evaluated. Preventive measures should be taken against $\mathrm{CN}$. In moderate and severe chronic kidney disease; low or iso-osmolar contrast agent should be used. It is recommended to minimize the volume of contrast medium. If we formulate it, the total contrast volume / GFR ratio should be $<3.7[8,9]$. High-dose statins $(20-40 \mathrm{mg}$ rosuvastatin, 80 $\mathrm{mg}$ atorvastatin) are recommended in this patient group. Statiler antienflamatuar ve antioksidan etkileriyle böbrek hasarını azaltırlar. The PRATO-ACS (Protective Effect of Rosuvastatin and Antiplatelet Therapy on Contrast-Induced Acute Kidney Injury and Myocardial Damage in Patients with Acute Coronary Syndrome) study [10] showed that 30-day renal and cardiovascular events were significantly reduced in 
patients given high-dose statins after percutaneous coronary intervention. If the estimated contrast volume is $<100 \mathrm{ml}$, pre- and post-hydration with isotonic saline is recommended [9]. While hydration is done at $1 \mathrm{ml} / \mathrm{kg} /$ hour for 12 hours before the procedure, this hydration is continued for 24 hours after the procedure. Alternatively, special hydration regimens such as infusion of normal saline adjusted to central venous pressure or furosemide with matched infusion of normal saline can be applied. In patients with severe chronic kidney disease, prophylactic hemofiltration can be performed for 6 hours before complex percutaneous coronary intervention [9]. Hemodialysis is not recommended in preventive approach.

\section{Conclusion}

$\mathrm{CN}$ is a complication of acute kidney injury that can lead to severe renal failure. However, the occurrence of this complication can be reduced by modifying risk factors and taking preventive measures.

\section{References}

1. Grundmann F, Müller RU, Hoyer-Allo KJR, Späth MR, Passmann E, et al. (2020) Dietary restriction for prevention of contrast-induced acute kidney injury in patients undergoing percutaneous coronary angiography: a randomized controlled trial. Scientific Reports 10: 5202. Link: https://go.nature.com/3fD6UHU

2. Büyüklü $M$, Bakırcı EM, Değirmenci H, Ceyhun G, Topal E (2017) ContrastInduced Nephropathy: Management by Antioxidant Therapy. Koşuyolu Heart J 20: 59-62

3. Kelemen JA, Kaserer A, Jensen KO, Stein P, Seifert B, et al. (2020) Prevalence and outcome of contrast-induced nephropathy in major trauma patients. Eur $J$ Trauma Emerg Surg 1-7. Link: https://bit.ly/2V4oj2M

4. Persson PB (2005) Contrast-induced nephropathy. Eur Radiol 4: 65-69.

5. Lei L, Xue Y, Guo Z, Liu B, He Y, et al. (2020) Population attributable risk estimates of risk factors for contrast-induced acute kidney injury following coronary angiography: a cohort study. BMC Cardiovascular Disorders 20: 289. Link: https://bit.ly/36cbgmh

6. Wong PC, Li Z, Guo J, Zhang A (2012) Pathophysiology of contrast-induced nephropathy. Int J Cardiol 158: 186-192. Link: https://bit.ly/2JdjOR9

7. Everson M, Sukcharoen K, Milner Q (2020) Contrast-associated acute kidney injury. British Journal of Anaesthesia 20: 417-423. Link: https://bit.ly/39juhoF

8. Giacoppo D, Gargiulo G, Buccheri S, Aruta P, Byrne RA, et al. (2017) Preventive strategies for contrast-induced acute kidney injury in patients undergoing percutaneous coronary procedures: Evidence from a hierarchical Bayesian network meta-analysis of 124 trials and 28240 patients. Circ Cardiovasc Interv 10: e004383. Link: https://bit.ly/33IDSb4

9. Neumann FJ, Sousa-Uva M, Ahlsson A, Alfonso F, Banning AP, et al. (2019) ESC/EACTS Guidelines on myocardial revascularization. European Heart Journal 40: 87-165. Link: https://bit.ly/3q88hDd

10. Leoncini M, Toso A, Maioli M, Tropeano F, Badia T, et al. (2014) Early high-dose rosuvastatin and cardioprotection in the protective effect of rosuvastatin and antiplatelet therapy on contrast-induced acute kidney injury and myocardial damage in patients with acute coronary syndrome (PRATO-ACS) study. Am Heart J 168: 792-797. Link: https://bit.ly/368WgFB

Discover a bigger Impact and Visibility of your article publication with

Peertechz Publications

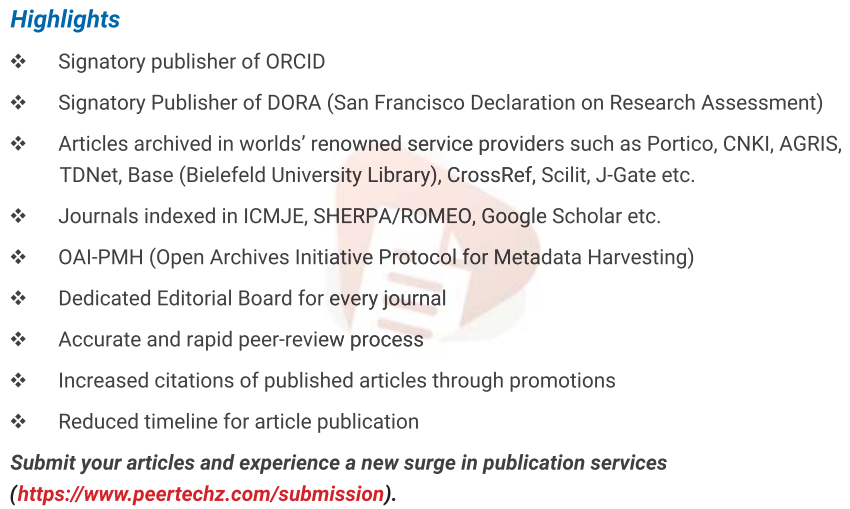

Copyright: @ 2020 Değirmenci H, et al. This is an open-access article distributed under the terms of the Creative Commons Attribution License, which permits unrestricted use, distribution, and reproduction in any medium, provided the original author and source are credited. 